Jurnal Ilmu Budaya, Vol. 17, No. 2 Februari Tahun 2021

\title{
MENYINGKAP IDEOLOGI PATRIARKI DALAM KISAH 1001 MALAM: KAJIAN DEKONSTRUKTIF
}

\author{
Essy Syam, Qori Islami Aris \\ Universitas Lancang Kuning \\ Email:essy_fib@yahoo.com,qoriislamibintiaris@gmail.com
}

\begin{abstract}
This writing analyzes a popular Malay text entitled Kisah 1001 Malam (Arabian Nights). This analysis shows that from the perspective of patriarchal ideology, a man is signified as strong and powerful figure. On the other hand, the analysis shows that the strong and powerful figure in the text is not the man but a woman instead. It is shown by presenting the man character who fails to fulfill his role as the savior or the problem solver, thus, the role is taken by a woman character. Thus, this analysis applies descriptive analysis in which the result of the analysis is described vividly. From the description, it will show patriarchal ideology which places man as the powerful figure is replaced by woman who is strong and smart.
\end{abstract}

Keywords: Kisah 1001 Malam (Arabian Nights), Patriarchal ideology, Deconstruction.

\section{Pendahuluan}

Ideologi patriarki diterapkan
hampir di seluruh kebudayaan
masyarakat dunia. Ideologi ini
mengakar sehingga menjadi sesuatu
yang ajeg dan berterima bagi mereka.
Masyarakat Timur Tengah, adalah
contoh masyarakat yang sangat kuat
menerapkan ideologi ini dalam
kehidupan sosial mereka. Penerapan
ideologi patriarki yang lebih
menekankan pada penafsiran secara

dangkal menimbulkan persepsi yang menempatkan kaum laki-laki berada pada posisi yang lebih menguntungkan dari pada perempuan. Ketika patriarki dengan sangat sederhana dimaknai sebagai kekuasaan seorang laki-laki terhadap perempuan, maka bermunculan persepsi dan tindakan yang tidak menyenangkan oleh kaum laki-laki terhadap perempuan. Hal ini muncul karena pemahaman ideologi patriarki yang tidak holistik. Bila 
Jurnal Ilmu Budaya, Vol. 17, No. 2 Februari Tahun 2021

ideologi ini dipahami secara holistik, maka ideologi patriarki tidak hanya dimaknai sebagai kekuasaan laki-laki terhadap perempuan, namun secara lebih seimbang akan dimaknai sebagai tanggung jawab, perlindungan, pengayoman dan hal-hal lain yang menyeimbangkan posisi laki-laki dan perempuan sesuai aturan yang ditetapkan.

Namun dalam kenyataannya, sebagian besar masyarakat cenderung memahaminya secara parsial sehingga menimbulkan konflik dalam relasi laki-laki dan perempuan. Masalah relasi ini memicu munculnya kajian dan pembahasan yang menyorot bagaimana hubungan antara laki-laki dan perempuan. Salah satu poin yang menjadi konflik adalah adanya persepsi bahwa kaum perempuan tidak mendapatkan kebebasan sehingga muncul berbagai perjuangan dan gerakan perempuan yang memperjuangkan kebebasannya.

Kondisi masyarakat yang patriarkis itu tidak hanya dapat terlihat dalam kehidupan sehari-hari, namun juga tercermin dari karya-karya yang muncul dalam masyarakat tersebut. Salah satu karya yang menarik untuk dibahas adalah Kisah 1001 Malam yang sudah sangat terkenal. Kisah ini menggambarkan kehidupan masyarakat Timur Tengah karena itu fokus kajian akan membahas ideologi patriarki dalam masyarakat Timur Tengah. Poin yang menarik dari kajian ini adalah menyingkap benarkah ideolog patriakhi yang diterapkan dalam masyarakat Timur tengah benarbenar menempatkan laki-laki pada posisi yang superior dan sebaliknya menempatkan perempuan pada posisi yang inferior yang tercermin dalam teks Kisah 1001 Malam.

\section{Tinjauan Pustaka}

Kajian-kajian yang menganalisis patriarki sangat banyak dilakukan, namun kajian patriarki yang menyorot teks Kisah 1001 Malam masih belum dilakukan, karena itulah tulisan ini akan menambah khasanah penelitian yang mengkaji ideologi patriarki yang 
Jurnal Ilmu Budaya, Vol. 17, No. 2 Februari Tahun 2021

mengkhususkan pada kajian teks

Kisah 1001 Malam.

Terkait dengan hal tersebut, maka terdapat beberapa kajian yang relevan. Diantaranya sebuah kajian yang menyoroti Budaya Patriakhi di Indonesia yang ditulis oleh Ade Irma dan Dessy Hasanah Siti A dari Prodi Ilmu Kesejahteraan Sosial, Universitas Padjajaran, pada tahun 2017. Tulisan ini memandang ideologi patriarki di Indonesia sebagai penyebab yang membelenggu perempuan. Hal ini merupakan masalah klasik yang memandang posisi perempuan hanya pada ranah domestik sehingga penegakan hukum menjadi lemah (Sakina \& A., 2017).

Kajian terkait lainnya adalah sebuah kajian berjudul "Perempuan, Budaya Patriarki dan Representasi," oleh Andy Omara dalam Jurnal Mimbar Hukum pada tahun 2004. Tulisan ini mengetengahkan gagasan bahwa budaya patriarki yang mendudukkan perempuan tidak sejajar dengan laki-laki mempengaruhi peran perempuan di masyarakat (Omara, 2004).

Kajian relevan berikutnya adalah sebuah tulisan berjudul "Pengaruh Budaya Patriakhi Terhadap Pemahaman Agama yang Keliru" yang ditulis oleh Nina Nurmila pada tahun 2015, dari Universitas Islam Negeri Sunan Gunung Djati, Bandung. Tulisan tersebut diterbitkan pada Jurnal Karsa. Tulisan ini menyorot ketidakadilan relasi yang ada dalam masyarakat sehingga perlu pemahaman agama yang benar (Nurmila, 2015).

\section{Konsep}

\subsection{Ideologi Patriarki}

Patriarki secara umum berarti "aturan dari pihak ayah". Istilah ini digunakan secara luas dengan pengertian-pengertian yang saling menjelaskan, yang pada intinya menjelaskan bagaimana laki-laki dianggap lebih superior dari perempuan (Kuper dan Kuper, 2000: 734).

Patriarki merupakan sistem budaya dimana kehidupan diatur 
Jurnal Ilmu Budaya, Vol. 17, No. 2 Februari Tahun 2021

dalam sistem 'kebapakan'. Patriarki merupakan ideologi yang mengacu pada tatanan masyarakat yang berdasarkan garis bapak. Dengan demikian patriarki merujuk pada masyarakat yang memiliki kekhasan dimana masyarakat tersebut diatur atau dipimpin oleh bapak atau kaum lakilaki (Adji dkk, 2009:1). Dengan demikian, konsekuensinya segala aturan dan keputusan berada di tangan laki-laki. Dengan menempatkan lakilaki sebagai pengatur dan pembuat keputusan, ideologi ini pada dasarnya memberikan tanggung jawab yang sangat besar kepada seorang laki-laki untuk mengatur keluarganya pada tataran yang kecil sampai mengatur negara pada tataran yang lebih besar.

Dengan meletakkan kekuasaan di tangan laki-laki, istilah ini, lalu, digunakan untuk menyorot hubungan kekuasaan antara laki-laki dan perempuan yang di dalamnya dianggap adanya dominasi laki-laki terhadap perempuan yang direalisasikan lewat berbagai media dan cara (Bhasin dalam Adji, 2009: 2). Dalam penerapan ideologi patriarki ini menimbulkan cara pandang yang beranggapan bahwa perempuan secara kodrati lebih lemah dari laki-laki.

Namun berbeda dari pandangan tersebut, Simone de Beauvoir tidak melihat kondisi yang menempatkan perempuan pada posisi yang lemah ini sebagai suatu sistem yang sudah ada sejak awal interakasi laki-laki dan perempuan. Beauvoir menilai sistem patriarki tidak terdapat pada masyarakat primitif karena ia tidak menemukan adanya institusi, sistem waris atau undang-undang yang menjelaskan tentang ketidaksetaraan jender. Bahkan agama sekalipun tidak menunjukkan hal ini. Karena itulah Beauvoir menyimpulkan bahwa perbedaan perlakuan dan posisi lakilaki dan perempuan bukan ditimbulkan oleh ideologi patriarki namun lebih disebabkan oleh bentukan proses kultural yang berlangsung lama dan terus menerus. Namun demikian Beauvoir tidak pula meyakini adanya kehidupan yang matriakhal (Adji, 2009: 4). 
Jurnal Ilmu Budaya, Vol. 17, No. 2 Februari Tahun 2021

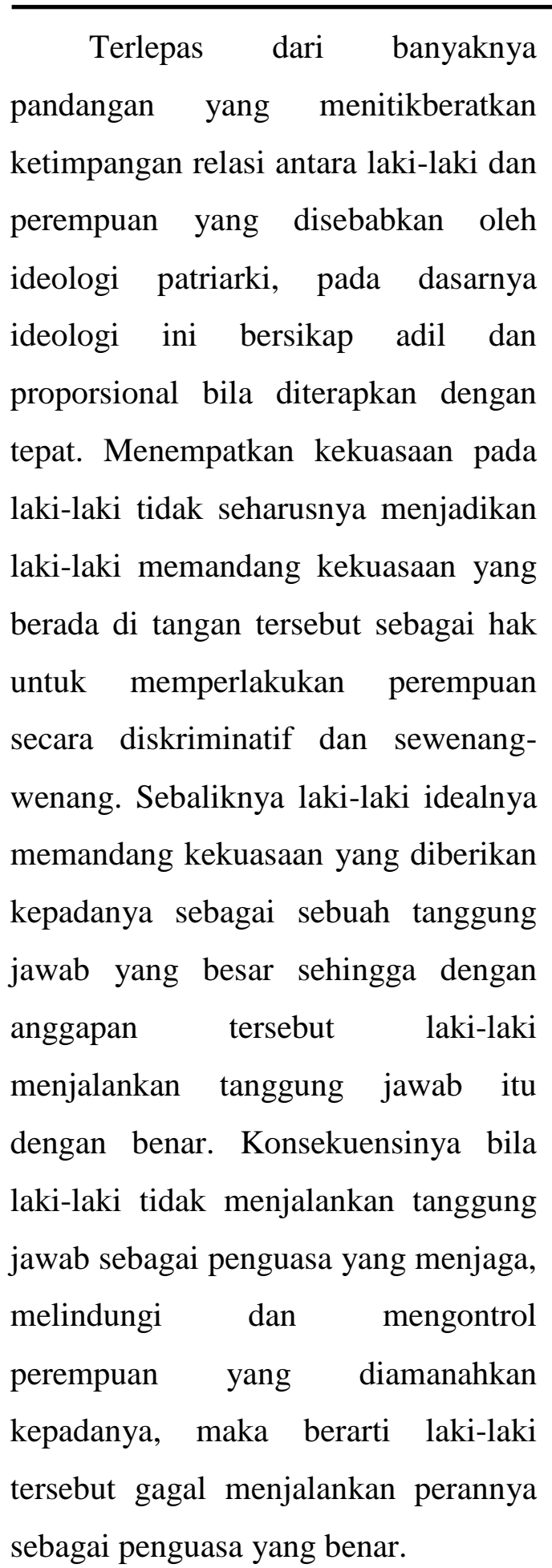

\subsection{Dekonstruksi}

Dekonstruksi merupakan teknik membaca yang meyakini bahwa budaya adalah teks sehingga semua produk budaya dapat diperlakukan sebagai teks. Dengan demikian, teks yang menjadi objek kajian tidak selalu teks tertulis tapi juga teks budaya (cultural texts). Hal ini dipertegas oleh Agger (dalam Syam 2018) yang mengungkapkan bahwa:

Deconstructors assume that culture is a text. The boundaries of literary texts expanded to include all manners of culture and performances and artefacts, from television and film to textbook and science. Cultural 
Jurnal Ilmu Budaya, Vol. 17, No. 2 Februari Tahun 2021

deconstruction is possible only if we make assumption that the diverse cultural products can be read.

Dalam menerapkan pembacaan dekonstruksi, maka kajian ini memfokuskan perhatiannya pada bagian-bagian yang dianggap sepele atau terpinggirkan (marginalia) namun bagian-bagain ini ternyata memiliki kemampuan untuk membongkar keseluruhan teks. Dengan demikian, bagian-bagian yang dianggap sepele ini ternyata merupakan bagian yang signifikan karena dapat mempengaruhi keseluruhan teks. Sebuah teks yang tersusun, terstruktur dan terbagun dengan baik, namun ketika teks itu memiliki bagian-bagian kecil yang membuat teks tersebut tidak memiliki makna yang utuh dan padu, maka teks tersebut tidak dapat lagi dikatakan tersusun dengan baik. Jadi, marginalia ini adalah bagian yang signifikan.

Selain itu, poin lain yang disorot dalam penerapan metode pembacaan dekonstruktif ini adalah mencari aporia. Aporia merupakan bagian teks yang tidak konsisten (inconsistence), bagian yang tidak koheren (incoherence), bagian yang ambigu (ambiguous) dan bagian yang mengandung kontradiksi (contradiction). Jadi, aporia ini memperlihatkan bahwa sebuah teks yang ditulis dengan baik ternyata di dalam teks itu sendiri memiliki elemen-elemen yang dapat merusak keutuhan dan kesatuannya sendiri. Dengan adanya aporia ini, sebuah teks ternyata dibangun di atas kontradiksi, ketidakkoherenan, dan ketidakkonsistenan. Dengan menemukan aporia di dalam teks, maka sebuah teks mengkhianati dirinya sendiri karena ktidakkonsistenannya mengungkapkan suatu pesan.

Pembacaan dekonstruktif ini menyoroti permasalahan di dalam teks (bukan bertujuan untuk pemaknaan atau menyelesaikan masalah), dengan cara mensubversi kestabilan sebuah teks. Selain itu, dekonstruksi tidak bekerja berdasarkan keraguan yang acak namun dengan pengusikan yang 
Jurnal Ilmu Budaya, Vol. 17, No. 2 Februari Tahun 2021

teliti dalam proses pemaknaan sebuah teks.

Dekonstruksi menekankan pembacaan dekonstruktif dengan metode pembacaan yang mengekspresikan kegagalan sebuah teks dan menampilkan kelemahan secara keseluruhan. Dengan demikian, sebuah teks dapat diusik dengan ketidakkonsistenannya,

ketidakkoherenannya dan kontradiksinya (Sarup dalam Syam, 2018).

\section{Metode Penelitian}

Kajian ini membongkar ideologi patriarki dalam teks Kisah 1001 Malam secara dekonstruktif. Dengan demikian, kajian ini merupakan sebuah studi kepustakaan dimana kajian dilakukan dengan mengumpulkan data-data kepustakaan.

Tahap pertama penelitian ini dilakukan dengan mengidentifikasi data-data yang terkait dengan ideologi patriarki dalam teks Kisah 1001 Malam, selanjutnya dilakukan analisis terhadap data-data tersebut.
Kajian ini merupakan suatu analisis deskriptif dimana kajian ini bertujuan menggambarkan fenomena yang ada. Dalam hal ini kajian ini mendeskripsikan hasil pembongkaran terhadap ideologi patriarki dalam teks tersebut. Selanjutnya, dalam menampilkan hasil kajian, kesimpulan ditarik secara induktif dimana gambaran-gambaran spesifik yang dipaparkan menuntun pada gambaran umum tentang topik yang dibahas.

\section{Pembahasan}

Hasil kajian ini memperlihatkan bahwa ideologi patriarki yang menempatkan laki-laki sebagai sosok yang kuat dan berkuasa yang ditunjukkan dalam teks Kisah 1001 Malam ini, ternyata secara dekonstruktif, dimaknai bertentangan dari penerapan ideologi patriarki. Hal ini dapat ditemukan ketika peran lakilaki yang kuat dan berkuasa, dalam teks ini digantikan oleh peran perempuan yang kuat dan cerdas sehingga berhasil menjadi penyelamat 
Jurnal Ilmu Budaya, Vol. 17, No. 2 Februari Tahun 2021

dan problem solver dari persoalan yang dihadapi.

Dalam teks Kisah 1001 Malam terdapat beberapa kejadian yang memperlihatkan bagaimana ideologi patriarki diterapkan dalam kehidupan masyarakat. Dalam teks tersebut digambarkan besarnya kekuasaan seorang laki-laki dalam membuat keputusan, apalagi tokoh laki-laki tersebut adalah seorang raja. Namun di sisi lain, teks ini juga memperlihatkan keadaan yang berbeda dengan menunjukkan peran besar seorang perempuan dalam menyikapi permasalahan yang timbul dari keputusan sang raja. Dengan demikian, dapat ditemukan dua kondisi yang berbeda yang menarik untuk dibahas. Dalam pembahasan ini, pertama akan dibahas penerapan ideologi patriarki yang menempatkan kekuasaan di tangan laki-laki, lalu pada bagian selanjutnya akan dibahas peran penting perempuan dalam merespon kekuasaan laki-laki.

\subsection{Ideologi Patriarki Kisah 1001 Malam}

Kisah

1001

Malam memperlihatkan besarnya peran dan kekuasaan seorang laki-laki karena itulah ideologi patriarki sangat jelas terlihat dengan menempatkan sosok laki-laki sebagai sosok yang berkuasa, apalagi tokoh yang ditampilkan dalam teks ini adalah seorang raja (sultan). Dalam teks ini sosok laki-laki sebagai tokoh utama merupakan seorang yang berkuasa, seorang yang membuat keputusan, yang menentukan kehidupan orang lain (dalam hal ini rakyatnya). Ia juga digambarkan sebagai sosok yang kuat dan tegar.

\subsubsection{Laki-laki sebagai penguasa}

Sebagai raja, Sultan Syahriar sangat berkuasa. Dengan kekuasaannya ia berbuat sesuai keinginan walaupun keinginannya itu menimbulkan kemudaratan bagi orang lain. Karena kekuasaannya tersebut, perintahnya selalu dituruti walaupun bertentangan dengan hati nurani orang yang menjalankan perintahnya tersebut. Hal ini terlihat dari apa yang dirasakan oleh Perdana Menteri yang tidak menyetujui perintah Sultan untuk 
Jurnal Ilmu Budaya, Vol. 17, No. 2 Februari Tahun 2021

mencarikan perempuan yang akan

dinikahi Sultan, lalu dibunuh keesokan harinya, "Perdana menteri menjadi orang yang paling bersedih. Di satu sisi ia tidak setuju dengan perbuatan Sultan, namun Sultan justru menugaskannya untuk mencari gadis yang akan dijadikan pengantin satu malam" (Kuswardhani, 2017:2).

\subsubsection{Laki-laki sebagai pembuat keputusan}

Sultan Syahriar sebagai penguasa memiliki kekuasaan penuh dalam memutuskan persoalan yang terjadi dalam wilayah kekuasaannya. Keputusannya tidak hanya terkait dengan orang-orang sekeliling, namun juga bagi hampir dalam segala aspek kehidupan rakyatnya.

Sebagai seorang penguasa yang membuat keputusan yang menentukan baik buruknya kehidupan rakyatnya, Sultan Syahriar dituntut untuk selalu arif dan bijaksana dalam setiap keputusan yang diambilnya. Namun, kenyataannya Sultan Syahriar tidak selalu bertindak bijaksana dalam memutuskan suatu perkara. Hal ini dapat dilihat dari keputusan yang dibuatnya untuk membunuh setiap wanita yang dinikahinya setiap hari. Keputusannya ini tentu saja memberikan pengaruh yang buruk bagi rakyatnya. Rakyat menjadi ketakutan karena mesti kehilangan anak perempuan setiap hari. Keadaan seperti ini berlangsung lama. "Cukup lama penduduk kerajaan hidup dalam kecemasan. Setiap malam, para orang tua yang memiliki anak perempuan menangis. Semua itu karena ulah Sultan mereka", (Kuswardhani, 2017:1).

Namun Sultan tidak mempedulikan dampak yang ditimbulkan oleh keputusan yang dibuatnya itu. "Setiap hari ia menikahi seorang gadis. Keesokan harinya ia mengirim gadis itu kepada algojo istana untuk diakhiri hidupnya. Tindakan Sultan mejadi teror bagi penduduk kerajaan" (Kuswardhani, 2017).

\subsubsection{Laki-laki sebagai Sosok yang Kuat}

Pada satu sisi, teks Kisah 1001 Malam menggambarkan sosok Sultan dengan gambaran yang positif. Sultan digambarkan sebagai sosok yang baik sehingga ia dihormati dan dicintai rakyatnya. Selain itu Sultan Syahriarj uga digambarkan sebagai seorang yang kuat. Sultan Syahriar sangat mencintai 
Jurnal Ilmu Budaya, Vol. 17, No. 2 Februari Tahun 2021

istrinya, namun istrinya berkhianat dengan menjalin hubungan dengan laki-laki lain. Pengkhianatan istrinya tersebut membuatnya sakit hati dan melakukan pelampiasan dengan membunuh perempuan-perempuan yang dinikahinya dalam satu hari. Apa yang dilakukannya itu memperlihatkan bagimana ia memendam rasa marah dan dendam. Pengkhianatan istrinya sebenarnya membuatnya sangat sedih dan kecewa, namun Sultan Syahriar menutupi kesedihannya dengan menghukum wanita-wanita yang dinikahinya. Tindakan ini ia lakukan untuk memperlihatkan bahwa ia adalah seorang yang kuat dan berkuasa. Sebuah tindakan untuk menutupi keterpurukan dirinya.

\subsection{Mendekonstruksi Ideologi Patriarki}

Pada satu sisi, teks Kisah 1001 Malam mengedepankan superioritas laki-laki, namun di sisi lain, teks ini secara dekonstruktif dapat dimaknai secara berbeda karena teks ini juga menampilkan kelemahan laki-laki dan disaat yang sama mengedepankan kekuatan dan kecerdasan perempuan.

\subsubsection{Laki-laki sebagai Sosok yang Lemah}

Sebagian besar teks Kisah 1001 Malam menggambarkan masyarakat patriarkis yang menempatkan laki-laki pada posisi yang lebih tinggi dari perempuan sehingga peran laki-laki sebagai pembuat keputusan dan penguasa sangat jelas tergambar. Namun secara dekonstruktif, teks ini juga mengungkapkan hal-hal yang membongkar pemaknaan yang telah diungkapkannya.

Pada pembahasan sebelumnya sudah dijelaskan bahwa teks ini menggambarkan sosok laki-laki yang berkuasa, yang memimpin, yang membuat keputusan, yang menentukan kehidupan orang-orang di sekelilingnya. Gambaran-gambaran tersebut menempelkan label positif pada sosok laki-laki. Namun di sisi lain, teks ini juga menampilkan gambaran yang kurang positif terhadap sosok laki-laki, dalam hal ini sosok Sultan Syahriar. Sultan Syahriar 
Jurnal Ilmu Budaya, Vol. 17, No. 2 Februari Tahun 2021

digambarkan sebagai laki-laki yang lemah. Pengkhianatan yang dilakukan istrinya membuatnya menjadi kehilangan kontrol diri. Rasa marah dan dendam akibat pengkhianatan itu mengubahnya menjadi seorang yang kejam dan kehilangan hati nurani. "Namun kini Sultan telah berubah, menjadi seorang yang kejam dan berhati dingin", (Kuswardhani, 2017:1). Padahal sebelumnya ia adalah seorang raja yang dicintai rakyatnya. Perubahannya yang sangat menonjol ini memperlihatkan kelemahannya sebagai seorang laki-laki dan sebagai seorang Sultan.

\subsubsection{Laki-laki sebagai Sosok yang Tidak Arif}

Selain menampilkan laki-laki yang lemah, teks ini juga menggambarkan sosok laki-laki yang tidak arif. Sultan Syahriar yang terluka karena pengkhianatan istrinya membuat keputusan yang tidak arif dan tidak manusiawi dengan membunuh wanita-wanita yang dinikahinya dalam satu hari.
Keputusan ini menunjukkan bahwa Sultan kehilangan kebijaksanaannya dalam membuat keputusan. Yang lebih memperlihatkan ketidakarifannya adalah hilangnya kepercayaannya terhadap wanita, " Sultan menjadi kecewa, ia kehilangan kepercayaannya kepada wniata, ia menganggap semua wanita culas seperti istrinya yang terdahulu", (Kuswardhani, 2017:2). Bila Sultan Syahriar dapat berpikir jernih dan bertindak arif, ia tidak akan menyamaratakan semua wanita hanya karena perbuatan buruk seorang wanita saja, apalagi ia adalah seorang Sultan yang seharusnya dapat berpikir lebih baik dan bertindak lebih arif dengan tidak menyamaratakan semua wanita dengan istrinya yang berperilaku buruk.

\subsubsection{Perempuan sebagai Penolong Kaumnya}

Dalam masyarakat yang patriarkis, idealnya yang menjadi penolong, penyelamat dan orang yang melakukan tindakan penyelamatan adalah seorang laki-laki dengan atribut kelaki-lakiannya, namun sebaliknya 
Jurnal Ilmu Budaya, Vol. 17, No. 2 Februari Tahun 2021

teks ini menampilkan sosok wanita yang menjadi penolong kaumnya. Di saat banyaknya wanita yang terbunuh oleh Sultan Syahriar, Sarah, putri perdana menteri menawarkan dirinya untuk dinikahi Sultan agar ia dapat menghentikan perbuatan buruk sang Sultan. Ia berpikir mencari jalan untuk menyelamatkan wanita-wanita di kerajaan itu. "Sarah terus berfikir, ia ingin menyelamatkan para gadis dari kekejaman Sultan, ia tidak ingin mati konyol seperti gadis-gadis lain. Namun ia tidak ingin melarikan diri dari tanah kelahiran yang dicintainya. Apalagi bila harus meninggalkan ayah dan keluarganya" (Kuswardhani, 2017:1).

Rasa prihatinnya terhadap keluarga yang telah kehilangan anak perempuan membuat Sarah mengemukakann niatnya untuk menghentikan tindakan Sultan dengan menawarkan dirinya menjadi istri Sultan. Hal ini diungkapkannya dalam pembicaraannya dengan ayahnya.

Walaupun sangat berat akhirnya perdana menteri memenuhi keinginan putrinya dan Sarahpun menikah dengan Sultan. Dengan menikahi Sultan, Sarah menyelamatkan kaumnya dari tindakan keji Sultan. Dengan pernikahannya itu, Sarah berhasil menyadarkan Sultan dan menghentikan Sultan membunuh wanita-wanita lagi. Hal itu diakui Sultan kepada Sarah, dan Sultan bahkan berterima kasih karena Sarah telah membuatnya sadar akan kekhilafannya. "Sarah, kau telah membuatku percaya bahwa masih ada perempuan baik di dunia ini. Kau membuatku sadar kesalahan fatal yang telah kuperbuat sebelumnya. Aku ingin berterima kasih kepadamu" (Kuswardhani, 2017:11).

\subsubsection{Perempuan Sebagai Problem solver}

Teks Kisah 1001 Malam mengedepankan sosok wanita yang menjadi penolong dan problem solver. Sarah menolong kaumnya dengan menghentikan tindakan Sultan yang membunuh para wanita dengan semena-mena. Apa yang ia lakukan merupakan solusi dari masalah yang dihadapi rakyat di kerajaan itu. Sarah 
Jurnal Ilmu Budaya, Vol. 17, No. 2 Februari Tahun 2021

berhasil membuat
mendengarkan cerita-ceritanya dan
mengambil hikmah dari cerita-
ceritanya tersebut sehingga Sultan
menjadi sadar akan kesalahannya.
Kesadaran Sultan ini membuat Sarah
berhasil mejadi problem solver. Lebih
jauh lagi, cerita-cerita yang dikisahkan
Sarah tidak hanya membuat Sultan
sadar, tapi juga menginsiprasi Sultan
untuk menggumpulkan
membukunyanya agar lebih banyak
orang yang dapat mengambil hikmah
dari kisah kisah tersebut.

\subsubsection{Perempuan Sebagai Sosok yang Pintar}

Teks Kisah 1001 Malam menampilkan sosok wanita yang pintar. Dengan kepintarannya Sarah dapat menolong kaumnya dan penyelesaikan masalah yang dihadapi rakyat di kerajaan. Sarah berhasil membuat rencana dan menemukan cara untuk menghentikan kekejaman Sultan.

\section{Simpulan}

Teks Kisah 1001 Malam merupakan karya yang sangat terkenal dan sangat menarik untuk dikaji. Kajian ini menyoroti ideologi patriarki yang ditampilkan dalam teks tersebut. Secara dekonstruktif, pada permukaannya, teks ini memperlihatkan bagaimana ideologi patriarki yang diterapkan memberikan kekuasaan yang besar pada laki-laki, apalagi, tokoh laki-lakinya adalah seorang Sultan, seorang penguasa. Sultan memiliki kuasa penuh dalam membuat keputusan. Ia memegang kendali terhadap hidup mati rakyatnya. Sultan juga digambarkan sebagai sosok yang kuat dan tegar dalam menyikapi pengkhianatan istrinya.

Namun, secara dekonstruktif, teks ini membongkar pemaknaan yang disajikan itu. Secara dekonstruktif, sosok Sultan bukanlah seorang yang kuat, namun sebaliknya, Sultan adalah seorang yang lemah, yang dengan kelemahannya itu, menuntunnya membuat keputusan yang keliru dan tidak arif, yang menimbulkan masalah dalam kerajaannya. Dan teks ini, lalu 
Jurnal Ilmu Budaya, Vol. 17, No. 2 Februari Tahun 2021

menampilkan tokoh perempuan, tokoh penyelamat dan problem solver dari permasalahan dalam kerajaan ini. Tokoh tersebut juga hadir sebagai karakter perempuan yang kuat.

Jadi, ideologi patriarki yang menempatkan laki-laki sebagai sosok yang kuat dan berkuasa, diambil alih perannya oleh seorang perempuan.

\section{Daftar Pustaka}

Adji, Muhamad dkk. 2009. Perempuan dalam Kuasa Patriarki, Laporan Penelitian/buku. Bandung: Fakultas Sastra Universitas Padjajaran.

Irma, Ade dan Dessy Hasanah Siti.A. 2017. Menyoroti Budaya Patriakhi di Indonesia. Bandung: Serial work journal, Universitas Padjajaran, diunduh dari https://media.neliti.com/media/p ublications/181589-IDmenyoroti-budaya-patriarki-diindonesia.pdf

Kuper, Adam dan Jessica Kuper. 2000. Ensiklopedia Ilmu-ilmu Sosial. Jakarta: PT Raja Grafindo Persada

Kuswardhani, Dian Sukma, 2017. Cerita Rakyat Arab Saudi, Kisah Seribu Satu
Malam, diakses dari http://uniquelatestarticle.blogspo t.com/2017/07/cerita-rakyatarab-saudi-kisah-seribu.html

Nurmila, Nina. 2015. Pengaruh Budaya Patriakhi Terhadap Pemahaman Agama, Bandung: Jurnal Karsa, Universitas Islam Negeri Sunan Gunung Djati diakses dari Ejournal.stainpamekasan.ac.id

Omara, Andy. 2004. Perempuan, Budaya Patriakhi dan Representasi. Yogyakarta: Jurnal Mimbar Hukum, Universitas Gadjah mada. Diakses dari http://i-

lib.ugm.ac.id/jurnal/detail.php?d ataId $=2625$

Storey, John. 1993. An Introductory Guide to Cultural Theory and Popular Culture. London: Prentice Hall/ Harvester Wheatsheaf

Syam, Essy. 2018. Membongkar Nilai Kebaikan Dalam Kisah Nujum Pak Belalang: Suatu Kajian Dekonstruktif. Pekanbaru: Jurnal Ilmu Budaya, Fakultas Ilmu Budaya, Universitas Lancang Kuning. 